\title{
Grand Strateji Olarak Kuşak ve Yol İnsiyatifinde Arktik: Kutup İpekyolu'nun Çin-Rusya Enerji İş Birliğindeki Rolü
}

As a Grand Strategy Arctic on The Belt and Road Initiative: The Role of Polar Silk Road in Sino-Russian Energy Cooperation

Anıl Çağlar ERKAN ${ }^{1}$

Ayça EMINOĞLU²

Geliş tarihi: 20.06.2019, Kabul tarihi: 30.07.2019, Basım tarihi: 25.10.2019

Öz

Arktik son zamanlarda devletlerin diş politika stratejilerinde kendisine daha fazla yer edinmeye başlamışıır. Kendisini "Yakın Arktik Ülkesi” olarak tanımlayan Çin, dış politika stratejilerinde söz konusu coğrafyaya daha fazla önem vermeye başlayan aktörlerdendir. Çin tarafından yayımlanan Beyaz Kitap, Arktik stratejilerinin resmi dayanaklarından iken Pekin'in bölgeye atfettiği önemin en önemli göstergesi ise Arktik politikalarının grand strateji olarak ifade edilen Kuşak-Yol İnisiyatifi'nin tamamlayıcısı olarak ilan etmesidir. Bölge dinamikleri 1şığında Çin'in Arktik stratejilerinde işbirliği kilit rol oynamaktadır. İşbirliği noktasında gerek sahip olduğu nitelikler gerekse son dönemde yaşanan gelişmeler dolayısıyla Rusya, Çin için en mantıklı seçenektir. İki taraf için kazan-kazan niteliğindeki enerji de en önemli işbirliği alanı olarak ortaya çıkmaktadır.

Anahtar Kelimeler: Grand Strateji, Çin, Rusya, Enerji, Kutup İpek Yolu, Kuşak ve Yol Inisiyatifi, Arktik.

Jel Kodlatr: P28, P16, P13, P45, Q31, Q34, Q41.

\begin{abstract}
Arctic has begun to gain more place in the foreign policy strategies of the states. China which defines itself as a "Near Arctic State" is one of the actors who started to give more importance to this geography in their foreign policy strategies. While the White Paper which is published by China, is an official resource of the Arctic strategies, the most important evidence of the importance that Beijing attaches to the region is the declaration of Arctic policies as a complement to The Belt and Road Initiative so-called "grand strategy". In the light of regional dynamics, cooperation plays a key role in China's Arctic strategies. Russia is the most logical option for China because of both the qualifications it has and the recent developments at the point of cooperation. For both sides, win-win energy is the most important area of cooperation.
\end{abstract}

\footnotetext{
${ }^{1}$ Burdur Mehmet Akif Ersoy Üniversitesi, Öğretim Görevlisi, acerkan@mehmetakif.edu.tr https://orcid.org/0000-0001-9693-6556

2 Karadeniz Teknik Üniversitesi, İ̈BF Uluslararası İlişkiler Bölümü, Dr. Öğr.Üyesi, aeminoglu@ktu.edu.tr

https://orcid.org/0000-0001-6925-7339
} 
Keywords: Grand Strategy, China, Russia, Energy, Polar Silk Road, The Belt and Road Initiative, Arctic.

Jel Codes: P28, P16, P13, P45, Q31, Q34, Q41

\section{Giriş}

Genel anlamda devletlerin etkileşimleri temelinde şekillenen uluslararas1 ilişkiler olgusu, tarihin her döneminde farklı alanlar ve bakış açıları özelinde kendisini güncelleyerek lineer bir biçimde ilerlemektedir. Söz konusu ilerleme tamamen devletler arasındaki etkileşimlerin dinamizmiyle ifade edilebilecekken, bu durum tamamen uluslararası ilişkiler disiplininin dinamik bir karaktere sahip olduğunun anlaşılması bakımından da büyük önem taşımaktadır. Çalışma konusu açısından bakıldığında, önceki dönemlerde yıkıcı savaşların önlenmesi, teorik tartışmalar ve Soğuk Savaş dönemi politikalar gibi konular geniş çapta disiplinin kabul gören başlıkları arasında yer almaktayken; günümüz analizlerinde enerji konusu disiplin literatürüne yerleşmeye başlamıştır. Ayrıca enerji konusu, disiplin kapsamında birtakım gelişmeleri de tetikler hale gelmiştir. Daha somut ifade etmek gerekirse, öncelikle enerji konusunun disiplin literatüründe popülarite kazanmaya başlaması, doğrudan birtakım analizlerin gözden geçirilmesine ve bir nebze de olsa belirli çalışma konularıyla birlikte değerlendirilebilecek bölgesel çalışmaların da ağırlıklı olarak ele alınmasına neden olmaktadır.

Mevcut çalışma alanlarına ek olarak özellikle enerji olgusu ile ilişkilendirilebilecek coğrafyalara, gerek devletlerin stratejileriyle gerekse de bilim insanlarının çalışmalarıyla ilgilerinin artmasına birçok dönemde tanıklık edilmektedir. Petrolün kullanımıla birlikte Amerika Birleşik Devletleri'nin (ABD), kaynak bakımından zengin fakat istikrar bağlamında güçsüz olan Orta Doğu, Afrika coğrafyasının ve Büyük Satranç Tahtası'nın uygulama alanı olarak görülen Kafkasya ve Orta Asya coğrafyasının üzerine ilgi duyulan çalışma konusu ve devlet stratejilerinin uygulama alanı haline dönüşümü bu çerçevede değerlendirilmelidir. Ayrıca ilişkilerde temel faktör olarak nitelendirilecek olan etkileşimin dinamizmi, gerek devletler arası ilişkilerde gerekse bu etkileşimin inceleme alanı olarak nitelendirilebilecek uluslararası ilişkiler disiplininde olsun, dönemin şartlarıyla birlikte değerlendirildiğinde birtakım aktörlerin ön plana çıkmasında önemli bir itici güç olduğuna da tanık olunmaktadır. Örneğin Avrupa Kıtası aktörleri arasındaki etkileşimlerin önem kazandığ1 dönemde Birleşik Krallık'n, Fransa'nın, Almanya'nın; Soğuk Savaş döneminde iki kutuplu uluslararası sistemin süper güçleri olarak ifade edilen Sovyet Sosyalist Cumhuriyetler Birliği'nin (SSCB) lokomotifi Moskova'nın ve Batı bloğunun lideri olan ABD'nin; tek-çok kutuplu dünya düzeni tartışmaları çerçevesinde Rusya Federasyonu (Rusya), Çin Halk Cumhuriyeti'nin (Çin); ekonomi politiğin 
önem kazanmasıyla birlikte yine Çin, Rusya, Brezilya, Hindistan'ın; enerji faktörü ile birlikte de Rusya, Avrupa Birliği (AB), ABD, İran'nn literatür çalışmalarında ağırlıklı olarak ele alındığı gözlemlenmektedir. Bu doğrultuda günümüz uluslararası ilişkiler disiplininde Çin'in ön plana çımaya başlayan aktörlerin başında yer aldığını ifade etmek mümkündür. Çin'in ön plana çıkmaya başlamasını farklı çalışma konuları özelinde değerlendirebilmemiz mümkünken enerji olgusu ve son dönemlerde yaşanan gelişmelerle birlikte ele alınması, çalışmanın başlangıç noktasını oluşturmaktadır. Öncelikle Çin'in enerji olgusuyla ele alınması literatürde ağırlıklı olarak ele alınan kaynakların çatışma, karmaşa, dış politika dinamiği gibi konularının dışına çıkılarak işbirliği olgusunun bu bağlamda incelenmesi bakımından çalışmanın disipline önemli bir katkısı olacağ1 düşünülmektedir. Bu bağlamda, çalışmanın konusu Çin-Rusya arasındaki enerji işbirliğidir. Çalışma için asıı önemli olan nokta ise ilişkilerin genel olarak değerlendirilmesi değil, ilişkilerin son dönemde sahip olduğu nitelikler bağlamında önem kazanan Arktik coğrafyası ışığında ele alınmasıdır. Bu kapsamda, çalışmanın gelişim aşamasında Rusya ve Çin'in enerji alanında işbirliğine yönelten etkenlerle birlikte Çin'in "Grand Strateji" olarak nitelendirilen Kuşak ve Yol İnisiyatifidir ele alınacaktır. Söz konusu stratejinin Arktik coğrafyası ile ilişkilendirilmesi ise Çin tarafindan deklare edilen "Vision and Actions on Jointly Building Silk Road Economic Belt and 21st Century Maritime Silk. Road" belgesinde Arktik bölgesinin tam olarak ifade edilmemiş olmasına rağmen, yakın dönemde Kutup İpek Yolu (Polar Silk Road) projesinin hayati önem taşıyan bir strateji olarak deklare edilmesidir. Çalışmanın konusu olan bu değişim, tarafları enerji bağlamında işbirliğine yönelten önemli bir etken olarak Arktik ve dolayısıyla Çin'in önemli bir stratejisine Arktik bölgesinin dahil edilmesi, hayati bir dinamik olarak ele alınmaktadır. Belirtilen konu doğrultusunda çalışmada öncelikle Arktik coğrafyasının hem devletler arası etkileşimler hem de uluslararası ilişkiler disiplini açısından ön plana çıkmaya başlamasına değinilmiş ve bölgenin nitelik kazanmasında enerji konusunun etkisi incelenmiştir. Sonrasında bölge dinamiklerinde Rusya'nın rolüyle birlikte Çin'in üzerinde önemle durduğu stratejilerinden birisi kapsaminda değerlendirilen bölgenin taraflar arasındaki enerji bağlamında geliştirilen ilişkilerine ve işbirliğindeki rolüne değinilerek, projenin uluslararası ilişkiler disiplinine olası katkıları ele alınmıştır.

\section{Grand Strateji Kavramı}

Toprağın ve temel değerlerin dış tehditlere karşı korunması şeklindeki ana akım, ulusal güvenlik anlayışına dayanmaya devam edilse bile bu, ulusal güvenliği sağlama yolunda en iyi stratejinin ne olduğu sorusuna cevap bulamamaktadır. Bu bağlamda bir devletin dış politikasının hayati unsurunu grand strateji oluşturmaktadır (Schmidt, 2016: 197). Karasal devletlerin (territorial state) izledikleri uzun vadeli güvenlik ve dış politikaları olarak tanımlanabilen "grand strateji" (Danner, 2018: 2), Liddel Hart tarafindan 
"genel olarak savaşla ilişkilendirilen siyasal amaçlara ulaşabilmek için sabip olunan gücleri ve kaynaklar koordineli bir şekilde harekete geçirebilmenin en iyi yolu” olarak ifade edilmektedir (Ploberger, 2017: 290). Ancak grand stratejinin yüzeysel bir ifade ile sadece devletin farklı alanlardaki çıkarları doğrultusundaki hedeflerine ulaşma çabası olmadığını bu aşamada belirtmek gerekmektedir. Şüphesiz bu yöndeki yaklaşım, kavramın özellikle devletin çıkarlarının askeri boyutuna odaklanarak sinırlandırılmasına ve spesifik hedefler bağlamında geliştirilen stratejiler ile ciddi bir şekilde karıştırılmasına neden olacaktır. Öyle ki grand strateji, askeri boyut gibi devletin spesifik çıkar alanların ötesinde bir anlayışı ifade etmektedir. Grand strateji ile ilgili olarak Morgenthau'nun görüssleri de söz konusu ifadeyi destekler niteliktedir. Örneğin Morgenthau çalışmasında, grand stratejinin odağını ulusal çıkarları en doğrudan ilgilendiren uluslararası konum üzerinde etki yaratmak için ulusal gücün farklı unsurlarının koordinasyonuna kaydırmaktadır. Görüldüğü üzere Morgenthau, grand stratejinin merkezindeki askeri yönüne odaklanan bir anlayıştan söz etmemektedir ancak uluslararası konumda etkili olabilmenin askeri yönleri de kapsayabileceğini öne sürmektedir (Ploberger, 2017: 290). Bu bağlamda grand stratejinin politika ve askeri stratejilerden birisi değil ancak bir dereceye kadar hepsinden oluştuğu ifade edilebilir (Murray, 2011: 2-3).

Sonuç olarak bir devletin diş politikasının hayati unsuru olarak ifade edilen grand strateji ${ }^{3}$, devletin ulusal güvenlik hedefleri ve bu hedeflere ulaşmada kullanacağı en uygun araçların seçilmesi bağlamında sahip olduğu genel vizyon olarak tanımlanmakla birlikte üç aşamalı bir süreç olarak görülebilir. İlk olarak, dış politika alanındaki yetkililer devletin hayati nitelikteki güvenlik hedeflerini belirlemelidir. İkinci olarak, bu yetkililer hedeflere yönelik temel tehdit kaynaklarını tespit etmelidirler. Son olarak ise, yetkililer ulusal güvenlik hedeflerini geliştirmede kullanılabilecek diş politika seçenekleri bağlamında temel olarak siyasi, ekonomik ve askeri kaynakları belirlemelidir (Schmidt, 2016: 197).

\footnotetext{
3 Uluslararası ilişkiler literatüründe grand strateji ile ilişkili bir takım karşıt düşüncelerle karşılaşılmaktadır. Söz konusu ayrışma birçok açıdan gözlemlenmekle birlikte genel olarak devletlerin genel strateji bağlamındaki nitelikleri çerçevesinde ortaya çıkmaktadır. Devletin kapasitesini grand strateji bağlamında zorunlu gereklilik olarak ifade eden Williamson Murray söz konusu düşünürlerden birisidir. Murray'a göre "grand strateji sadece ama sadece büyük devletleri ilgilendiren bir konudur. Hiçbir küugük veya orta ölgekli devlet grand strateji oluşturma imkanma sahip değildir" (Murray, 2011: 1). Bu görüşe karşıllk olarak görüşler ifade edilmekte ve örneğin Hanna Samir Kassab "Grand Strategies of Weak States and Great Powers" başliklı kitabında "bütün devletlerin grand stratejileri olabileceği konusunu iddia etmektedir" (Kassab, 2018: 26).
} 


\section{2. Çin'in Grand Stratejisi Yeni İpekyolu Projesi: Tek Kuşak Tek Yol Girişimi}

Günümüz uluslararası sisteminde "yeni büyük güç" ve "yükselen güç" gibi ifadelerle nitelendirilen Çin, grand strateji çerçevesinde çalışmalar yürütmektedir. Xi Jinping'in ifadeleri de çalışmaları destekler niteliktedir. Öyle ki Xi, Çin'in uluslararası sistemdeki nihai hedefleri ve önümüzdeki on yıllarda bunların nasıl başaralı olması gerektiği ile ilgili düşüncelerini her firsatta dile getirmekle birlikte, bunlara ek olarak "bütünlesilk ve tutarl fikirler diə̌isinin ülke yönetimince benimsendiğiñ" de ifade etmektedir (Scrafton, 2018). Çin tarafindan belirlenen bütünleşik ve tutarlı fikirler dizisinin en önemlilerinin başında ise "Kussak ve Yol İnisiyatifi" yer almaktadır.

\subsection{Kuşak ve Yol İnisiyatifi}

Büyük öneme sahip girişimlerden birisi olan "Yeni İpek Yolu Girişimi", "Tek Kusak ve Tek Yol" ya da "Kusak ve Yol İnisiyatifi", Tekir ve Demir'e göre; "tartısmastz. Cin balkinn 1949 yulndan bu yana en iddiah politika programider" şeklinde nitelendirilmektedir (Tekir ve Demir, 2019: 266). 21. Yüzyllın en önemli kalkınma projelerinden biri olarak da nitelendirilen girişimin, Çin Devlet Başkanı Xi Jinping tarafından 2013 yll Eylül ayında Kazakistan'ın Nazarbayev Üniversitesi'nde yaptığı konuşmada "Tek Kuşak" olarak ifade edilen "İpek Yolu İktisadi Kusağı" hakkında bilgiler vermesi ve 2013 yll Kasım ayında ise Endonezya Parlamentosunda yaptığ1 konuşma sırasında, "Tek Yol" olarak bilinen "21. Yüryll Deniz İpek Yolu Projesi" hakkında da açıklamalar yapmasıyla somutlaşmaya başlamışıır ${ }^{4}$ (Hu, 2017: 108). Bundan kısa bir süre sonra Çin Komünist Partisi (ÇKP) Merkez Komitesi, Üçüncü Genel Oturumu sonucunda İpek Yolu Ekonomi Kuşağı ve 21. Yüzyıl Deniz İpek Yolu'nun inşasının teşvikine ve bundan sonra her iki projenin kısaca "Kuşak-Yol" Projesi olarak adlandırılmasına karar verildiğini bir bildirge ile ilan etmiştir. Böylece bu bildirge ile "Kuşak-Yol" Projesi resmi olarak devlet stratejilerinden biri olarak kabul edilmiştir (Durdular, 2016: 79). Projeyi hayata geçirme planı ise 14 Mart 2014 tarihinde Li Kequiand'ın açıkladığ1 Hükümet Çalışmaları Raporu'nda yer almıştır (Özdaşlı, 2015: 586).

Somutlaşan plan dahilinde, Çin ile Orta Asya, Orta Doğu ve Avrupa'yı yeniden birbirine bağlamayı hedefleyen ve dünya kamuoyunun ciddi ölçekte ilgisini çeken Kuşak-Yol projesi, iki ana bağlantıdan oluşmaktadır (Sevilla, 2017: 87). Bu bağlantılar, Jinping tarafından Kazakistan'a açılanan kara bağlantısı ile Endonezya'da açıklanan deniz yolu bağlantısıdır (Güner, 2018: 113). Projenin iki parçasından birisi olan "İpek Yolu İktisadi Kuşağı" kapsamında, Çin'in doğu kiyılarından Rotterdam'a kadar uzanan Avrasya Kara Köprüsü” kurulması ön görülmektir. Bununla birlikte “Tek Kuşak” ile

\footnotetext{
${ }^{4}$ Kuşak-Yol Girişimi terminolojisinde "Kuşak" karasal bir bağlantıyı "Yol" ise deniz rotaları aracılığı ile bağlantıyı nitelemek için kullanılmaktadır (Kohil, 2018: 4).
} 
Çin ile Moğolistan, Rusya, Orta Asya ve Güneydoğu Asya'nın bağlanması sağlanacaktır (Yiğenoğlu, 2018: 15). Örneğin "bir" olarak ifade edilen Bangladeş-Çin-Hindistan-Myanmar Ekonomik Koridoru (BCIM-EC) söz konusu bağlantılardan birisidir (Hu, 2017: 108).

Projenin diğer parçası olan "21. Yüzyıl Deniz İpek Yolu” kapsaminda ise Çin'in doğu kıyısı ve batıya doğru olan kısım, Güney Çin Denizi ve Hint Okyanusu aracilığ1 ile Avrupa’ya bağlanacaktır (Yiğenoğlu, 2018: 15). Bununla birlikte Çin’in Güneydoğu Asya kıyıları ile Hint Okyanusu, Arap Denizi ve Afrika, Avrupa'ya kadar uzanacak şekilde bir bağlantı haline gelecektir (Hu, 2017: 108). Deniz İpek Yolu güzergahı ise Güney Çin Denizi'nden başlayıp, Kalküta üzerinden Hint Okyanusu ile Kenya’ya ulaşan ve buradan da Kızıl Deniz ve Akdeniz üzerinden Venedik'e uzanacak bir rotadan oluşmaktadır (Özdaşl1, 2015: 586).

\section{Harita 1: Kuşak-Yol Projesi Güzergahları (Güneş, 2018)}

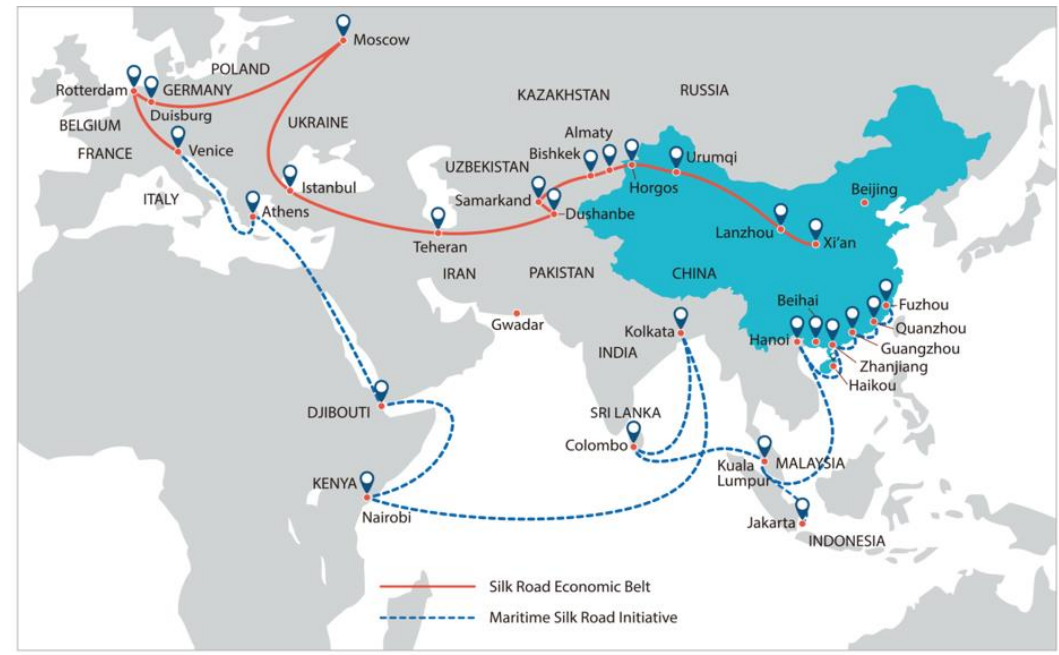

Sonuç olarak Kuşak-Yol bağlamında değerlendirilen iki parça birleştirildiğinde kara ve deniz olmak üzere 7 ana koridordan bahsedilmesi mümkündür. Bunlar, Çin'in batısından Avrupa'ya uzanan Yeni Avrasya Kara Köprüsü; Çin'in kuzeyinden Rusya'nın doğusuna uzanan Çin-MoğolistanRusya Koridoru; Çin'in batısından Türkiye'ye uzanan Çin-Orta Asya-Batı Asya Koridoru; Çin'in güneyinden Singapur'a uzanan Çin-Hindiçini Yarımadası Koridoru; Çin'in güneyinden Hindistan'a uzanan Çin-MyanmarBangladeş-Hindistan Koridoru; Çin'in güneybatısından Pakistan'a uzanan Çin Pakistan Koridoru ve son olarak da Deniz İpek Yolu olarak nitelendirilen güzergahtır (Kohil, 2018: 5). 
Harita 2: Çin'in Kuşak-Yol İnisiyatifi Ana Koridorları (ICRC, 2018).

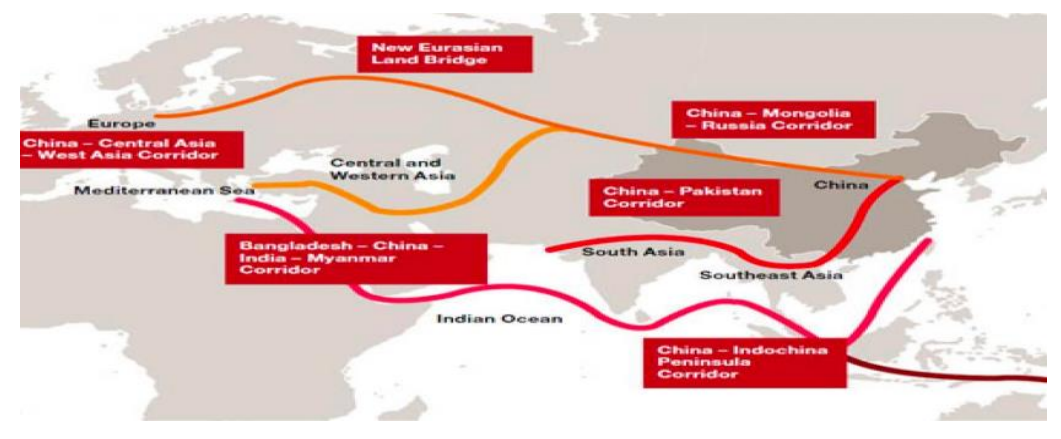

\subsection{Grand Strateji Perspektifinden Kuşak ve Yol İnisiyatifi}

Daha önceki satırlarda da ifade edildiği gibi grand stratejinin üç aşamalı bir süreç olarak irdelenmesi gerekmektedir. İlk aşamada devletin hayati güvenlik hedefleri yer almaktadır. Güvenlik hedeflerinden bazıları devletlere göre değişken bir yapıya sahip iken bazı hedefler ise her devlet için genelkabul gören bir niteliğe sahiptir. Dış politikanın temel hedeflerinden bir tanesi olarak devletler için değişmeyen ulusal güvenlik hedefleri şüphesiz varlıklarını sürdürebilme, güç elde etme ve bunlarla bağlantılı olarak uluslararası sistemde öncelikli konumda yer alabilmektir. Dolayısıyla güvenlik hedeflerinin bir devletin sinırlarına, ekonomik refahına, vatandaşlarının fiziksel varlığına ve sahip olduğu değerlere yönelik tehditleri tespit etmek, onları bertaraf etmek ve bu uğurda diplomatik, siyasi, ekonomik ve askeri imkanları kullanmakla ilgili olduğu söylenebilir (Kardaş, 2014: 328). Şüphesiz Çin için de bu güvenlik hedefleri geçerlidir.

Grand stratejinin ikinci aşaması, söz konusu güvenlik hedeflerine yönelik temel tehdit kaynaklarının belirlenmesidir. Dünyanın ikinci büyük ekonomisi olan Çin, ihracatta yüzde $12,76^{\prime}$ lık bir payla birinci sırada, yüzde 10,61'lik ithalatla ikinci sirada yer almaktadır (Dunford ve Liu, 2019: 147). Bu gibi birçok nedenden dolayı Çin'in güvenlik hedefleri bağlamında temel tehdit kaynaklarının, genel olarak ekonomi odağında gün yüzüne çıtı̆̆ gözlemlenmektedir. Çin'in 2010 yllında yayınlanan Ulusal Güvenlik Strateji Belgesindeki beyanlar da söz konusu odağın ekonomi ağırlıklı olduğunu destekler niteliktedir. Bu belgeye göre "Cin için mevcut șartlarda en önemli gïvenlik stratejisi, yakalamıs olduğu ekonomik büyüme trendini korumak ve ekonomik büyüme için engel teşkil edecek, sorunlar ortadan kaldrrmak ya da minimize etmektir" (Şöhret, 2011)

Ekonomik unsurların Pekin'in yükselişinin ana lokomotifi olmasıyla birlikte, devlet ideolojisindeki önemi de yine grand stratejinin bu temelde şekillenmesinin en önemli nedenidir. Bu noktada, öncelikle ekonomik 
unsurların Çin grand stratejisinin temelinde yer almasının devlet ideolojisi açısından önemine değinmek gerekmektedir. Çin devlet ideolojisine göre, Çin ekonomisi dünya ekonomisi ile yakından bağlantılıdır ve uluslararası arenadaki yükselişinin temelinde yatan en önemli unsurdur. Dolayisıyla ekonomideki herhangi bir gerileme, Çin devlet ideolojisine göre ülke için önemli bir tehdit olarak algılanmaktadır. Çünkü milliyetçi bakış açısıyla Çin'e göre ekonomik gerileme, ülkeyi önde gelen uluslar grubunda yer almaktan mahrum birakmaktadır (Ploberger, 2017: 292).

\section{Harita 3: Çin ve ABD'nin Ticaret Partnerlerinin Karşıllaştırılması (Desjardins, 2016)}

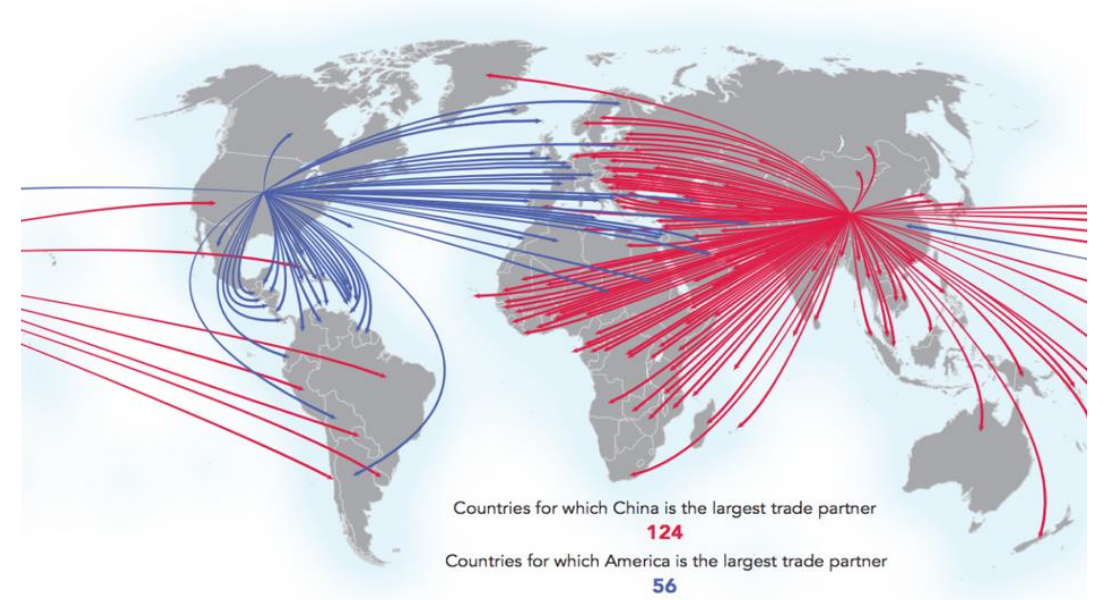

Kuşak-Yol Projesi ile ilgili olarak hükümet organları ve yetkililerin beyanları, grand stratejinin odağının ekonomi üzerinde yoğunlaşması açısından Çin devlet ideolojisini destekler niteliktedir. Örneğin, Çin Devlet Konseyi tarafından proje için yetkilendirilen Ulusal Kalkınma ve Reform Komisyonu da ekonomik odağı vurgulamakta ve Kuşak-Yol projesinin 2008 ylında yaşanan küresel mali krizin etkisiyle gün yüzüne çıkan ekonomik performans zayıflı̆̆ının aşılmasına yardımcı olacağı ifade edilmektedir (Ploberger, 2017: 294). Ayrica proje kapsamında, aksiyon planında kullanılan ifadeler ve resmi olarak beyan edilen amaçlar da ana odağın ekonomi üzerine yoğunlaştığını argümanını destekler niteliktedir. Örneğin, söz konusu aksiyon planına göre ana amaçlar "çok kutuplu bir dünyaya, ekonomike küresellessmeye, külttürel çeşitliliğe ve bilisim teknolojilerine yönelike eğgilimi kucaklayan "Kemer ve Yolu" ortaklasa insa etme girisimi, kïresel serbest ticaret rejimini ve açle. dünya ekonomisini bölgesel işbirliğ rubu içerisinde korumak için tasarlanmuşttr" şeklinde ifade edilmektedir (Çin Halk Cumhuriyeti Devlet Konseyi, 2015). Bunun yanı sıra aksiyon planı dahilinde "Ekonomik faktörlerin düzenli bir șekilde serbest akuşsm, kaynaklarn yükseke oranda tabsis edilmesini ve piyasalarm derin entegrasyonunu tessvik etmek; Kemer ve Yol boyunca ülkelerin ekonomi politika 
koordinasyonlarm sağlamak ve daha yüksek standartlarda derinlemesine bölgesel işbirlig̈ini yürütmek için teşvik etmek; ortaklaşa, herkese yarar sağlayan açı, kapsayıc ve dengeli bir bölgesel ekonomik işbirliği mimarisi olusturmak" şeklindeki ifadeler söz konusu destekleyici argümanlardandır (Çin Halk Cumhuriyeti Devlet Konseyi, 2015).

Grand stratejinin üçüncü aşamas1, ulusal güvenlik hedeflerini geliştirmede kullanılabilecek dış politika seçenekleri olarak temel siyasi, ekonomik ve askeri kaynakların dolayısıyla araçların saptanmasıdır. Politika bağlamında işbirliği mekanizmalarıyla birlikte ekonomik kaynaklar bu aşamada grand strateji olarak nitelendirilen Kuşak-Yol kapsamında büyük önem taşımaktadır. Bu doğrultuda, öncelikle işbirliği mekanizmaları açısından bakıldığında Çin, projenin inşasında ve bölgesel işbirliğinin gelişmesini teşvik etmek için çift yönlü ve çok taraflı işbirliği mekanizmalarından yararlanmaktadır. Şanghay İşbirliği Örgütü (ŞIÖ), ASEAN + Çin (10+1), Asya-Pasifik Ekonomik İşbirliği (APEC), Asya-Avrupa Toplantısı, Asya İş Birliği Diyalogu (ACD), Asya'da Karşlıklı İlişki ve Güven Oluşturma Tedbirleri Konferansı (CICA), Çin-Arap Devletleri İşbirliği Forumu (CASCF), Çin-Körfez İşbirliği Kurulu Stratejik Diyalogu, Büyük Mekong Alt Bölgesi Ekonomik İşbirliği (GMS) ve Orta Asya Ekonomik İşbirliği (CAREC)söz konusu çok taraflı mekanizmalardandır (Çin Halk Cumhuriyeti Devlet Konseyi, 2015). Çin hükümetine göre, 2018 yll sonuna kadar yaklassık olarak 890 milyar Amerikan Doları (dolar) hali hazırda yatırım yapıldığı, 4 trilyon dolar üzerinde daha yatırım yapılacağı (Harinder, 2018: 3) ve 21 trilyon doları bulacağı öngörülen maddi büyüklügüule birlikte KuşakYol Projesinin nitelikleri göz önüne alındığında, Pekin’in ekonomik olarak ciddi ölçüde kaynağa ihtiyaç duyduğu açıkça görülmektedir (Uluslararası Politika Akademisi, 2017). Dolayısıyla bu kaynakların temini için ciddi çalışmalar gerekmektedir. Öncelikle Çin tarafından üç yeni kurum oluşturulmuştur. Bu bağlamda Dünya Bankası'na alternatif olarak 100 milyar dolar sermaye ile kurulan Asya Altyap1 Yatırım Bankası (AIIB), 50 milyar dolar sermaye ile kurulan Yeni Kalkınma Bankası (önceki adı BRICS Bankası) ve 30 milyar dolar sermaye ile kurulan İpek Yolu Fonu projenin finansmanı noktasında ekonomik kaynak açısından Pekin'in en önemli yardımcılarındandır (Sheng, 2017: 239). Diğer yardımcılar bağlamında, ekonomik kaynak olarak ayrıca projeyi finanse etmek için Çin hükümeti önemli ölçüde proje tahsis etmeyi vaat etmiş ve buna ek olarak kalan kısmın da Çin Yatırım Şirketi, Çin Kalkınma Bankası Sermaye Şirketi ve Çin İhracat-İthalat Bankası tarafından karşılanacağı beyan edilmiştir. Söz konusu oluşumlara ek olarak Pekin ülke dışında birçok çalışma gerçekleştirmekte ve özellikle projeye finansman ve kaynak desteği verebilecek başta kuşak üzerindeki ülkeler olmak üzere diğer ülkelerde de lobi faaliyetleri gerçekleştirmektedir. Örneğin Özdaşlı'nın ifadesiyle "5 Haz̧iran 2014'te Çin-

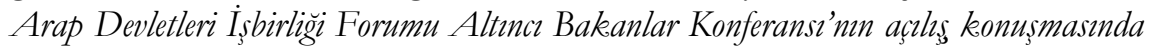


Jinping, "Tek Kuşak, Tek Yol” bedefine ulaşmak için Arap ülkeleri ile işbirliği yapmak istediklerini belirterek "İpek Yolu Rubu'nu yeniden canlandirlmasi için "omuz. omuza" çalışmak isteklerini ifade etmiştir" (Özdaşl1, 2015: 589).

\section{Harita 4: Asya Altyapı Yatırım Bankası Kurucu Üyeleri (Desjardins, 2016).}

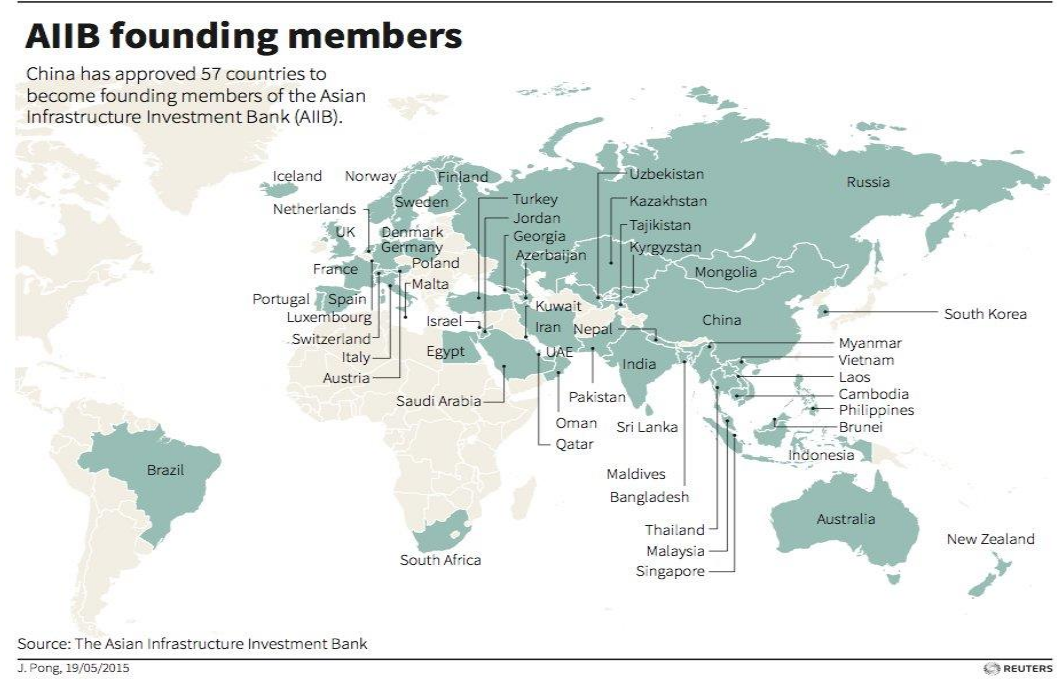

Sonuç olarak Çin tarafindan yürütülmekte olan Kuşak-Yol Projesi’ni grand strateji olarak nitelendirmek mümkündür. Bilindiği üzere Kuşak-Yol Projesi ile Çin, ülkenin siyasi, diplomatik, düşünsel, ekonomik ve finansal kaynaklarını ekonomik olarak karşılaşılabilecek hem iç hem dış kaynaklı zorluklar için harekete geçirmiştir (Scrafton, 2018). Dolayısıyla bu girişim, grand strateji bağlamında atılan önemli bir adımlardan birisidir. Yapılan analizler de söz konusu kabulü destekler niteliktedir. Örneğin Proje, Amerikan "Foreign Policy" dergisinde çıkan bir eleştiride Çin'in "Trans Pasifik Ortaklı̆̆ı'na (TPP)" cevabı şeklinde yorumlanmıştır. Farklı bir analizde ise, projenin küresel ekonomi açısından "game changer" (oyun değiştirici) unsur olduğu vurgulanmıştır (Uluslararası Politika Akademisi, 2017).

\section{Arktik ve Yeni Firsatlar}

Çin tarafindan ilan edilen Kuşak-Yol Projesi, deniz ticaret haritasının güncellenmesi ve 60 'tan fazla ülkeyi içeren bir işbirliği çerçevesine sahiptir. ${ }^{5}$

5 Eylül 2018 itibariyle Kuşak-Yol bağlamında etkileşimde olduğu uluslararası örgüt ve devletlerin sayıs 130'dan fazladır (Dunford ve Liu, 2019: 145). Bununla birlikte Mayis 2017'de Pekin'de düzenlenen ilk Kuşak ve Yol Forumu'na (Belt and Road Forum (BARF)) 130 ülke ve 70 uluslararası örgütlerin devlet başkanı ve delegasyonlarından 29 katılım olmuştur (Kohil, 2018: 4). 
Projenin temelinde, günümüz yüzyılının dinamikleri çerçevesinde bağların barış ve işbirliği içerisinde güçlendirilmesi yatmaktadır. Bu temel, uluslararası arenada meydana gelen değişimler ve ortaya çıkan olanaklar kapsamında projenin güncellenmesini zorunlu kılmaktadır. Çin hükümet yetkilileri de söz konusu zorunluluğun bilincinde hareket etmekte ve projenin güncelliğinin korunması yönünde çalışmalar yürütmektedirler. Örneğin 2013 vizyonuna güncel gelişmeler ış̧ğında yeni bölgeler eklenmesi, söz konusu çalışmalardan bir tanesidir. Yeni çalş̧malar dahilinde güncellenen vizyonda projenin kaderini temelden değiştirebilecek ve küresel ölçekte etki yaratabilecek bölgelerin başında Arktik yer almaktadır.

\section{Harita 5: Arktik Bölgesi (Anonim)}

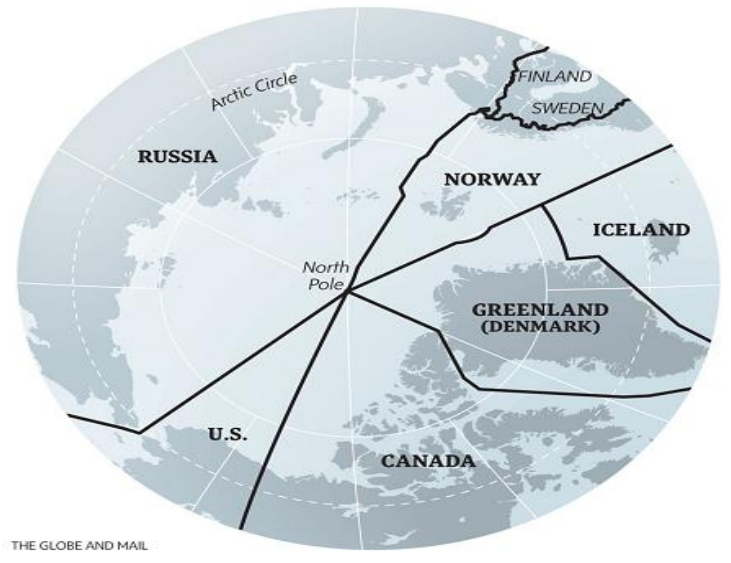

Uzun bir süre "terra nillius" olarak nitelenen ve 20. yüzyılın başlarına kadar hakkında tam olarak bilgi sahibi olunmayan Arktik, önemli ölçüde yakın geleceğin jeopolitik mücadele alanı olarak görülmektedir. Önceki dönemlerde coğrafi faktörlerden kaynaklanan şartların elverişsiz olması, bölgeyi yakın dönemlere kadar uluslararası sistemin büyük güçlerinin hegemonik paylaşımlarından izole tutmuşken (Ingenfald, 2010: 257), 27 milyon kilometrekarelik yüzölçümüne sahip olan Arktik bölgesinde yaşanan değişimler ve olası etkileri, coğrafyanın artık jeopolitik oyunun içine dahil edilmesine ortam hazırlamıştır. Arktik coğrafyasının öneminin artması nedenlerini teknolojik gelişmeler ile küresel ısınma başlıkları altında, ulaşım yolları ve hepsini kapsar nitelikte olan enerji olmak üzere sinıflandırmamız mümkündür. Daha açı bir ifadeyle, Arktik coğrafyasının uluslararası ilişkilerde önem kazanmasının temelinde teknolojik ilerlemelerle birlikte küresel çapta etkileri hissedilen iklim değişikliği gibi dinamikler yer almakta, bunlarla ilişkili olarak işbirliği, enerji ve ulaşım yolları gibi sonuçlar söz konusu önemi sağlamlaştırmaktadır (Sancak, 2019: 17).

Kuzey Kutup Bölgesi'ni kaplayan buzulların küresel çapta etkileri olan iklim değişikliğinin sonuçlarından birisi olarak erimeye başlaması, tüm 
uzmanlarca dünyanın dengesini baştan aşağı değiştirebilecek ekolojik felaket olarak nitelendirilmektedir ${ }^{6}$ (Westly, 2007). Ancak buna karşın ekolojik felaket olarak ifade edilen değişim, özellikle bölgeye yakın konumdaki birçok ülke için ekonomik ve siyasal açıdan önemli fırsatlara olanak sağlamaktadır. Bölgeye erişimin daha kolay hale gelmesiyle başlayan süreç, bilimsel çalışmalarla hız kazanmıştır. Elde edilen bulgular, önemli ölçüde Arktik’in ekonomik olarak yeni fırsatları bünyesinde barındırdı̆̆ını göstermektedir (Ingenfald, 2010: 257). Bulgular sonucunda ifade edilen söz konusu firsatlar ise birçok alanda olmakla birlikte, özellikle küresel ticaret rotalarına alternatifler, işbirliği, enerji kaynakları ve değerli minerallere erişim, olarak gün yüzüne çıkmaktadır (Young, 2012: 167). Arktik bölgesinin önemini özellikle enerji faktörü bakımından artıran gelişmeler, 1930'lu yılların ortasinda (Safanov, 2010: 112) dile getirilmeye başlanmış olsa da önemli ölçüde 2008 yılına dayanmaktadır. 2008 yılında ABD Jeoloji Araştırmaları Kurumu (U.S. Geological Survey), yaptığ1 araştırmalar sonucunda Arktik bölgesinde 90 milyar varil petrol,7 1.669 trilyon kübik feet doğal gaz ve 44 milyar varil doğal gaz sıvisı enerji kaynağı rezervi olduğunu açıklamıştır (Heinien ve diğerleri, 2014: 9). Söz konusu rakamlar dünya keşfedilmemiş doğal gaz rezervlerinin yaklaşık olarak yüzde 30'una ve keşfedilmemiş petrol rezervlerinin ise yaklaşık yüzde 14'ine karşıllk gelmektedir (Blunden, 2009: 122). Ayrica küresel enerji rezervlerinin yüzde 24'ü bu bölgede yer almakta (Gümrükçü, 2015: 12) ve bunun yaklaşık yüzde 84'ü ise açık deniz (offshore) alanlarında yer almaktadır (Hasanoğlu, 2015: 175).

Küresel çapta etkileri hissedilen ve buzulların erimesini tetikleyen iklim değişikliği, gün yüzüne çıkarılmamış enerji kaynakları ve değerli minerallere ulaşım olanaklarıyla birlikte, bunlarla ilişkili olarak taşımacılıkta farklı bir aşamaya geçişe olanak sağlayacak potansiyeldedir. Çünkü bölgede yaşanan değişimlerle birlikte yeni deniz ticaret ve enerji nakil hattı güzergahlarının ortaya çıkması beklenmektedir. Örneğin, Avrupa ve Doğu Asya limanları arasındaki mesafeyi önemli ölçüde azaltan Kuzey Deniz Yolu'nun (North Sea Route) (Sergunin ve Konyshev, 2014: 72) kullanılmaya başlanması bu bağlamda önemli gelişmeler arasındadır. Ayrıca yaklaşık olarak kırk yıl sonra

\footnotetext{
${ }^{6}$ İçinde bulunduğumuz yüzyılın sonunda (2100 yllında), en iyimser tahminlere göre deniz seviyesinde bir metre yükselme beklenmektedir (Akın, 2013: 15).

${ }^{7}$ Söz konusu rakamlar kayda değer ölçüde oranlara karşılık gelmekte ve karşılaştırmalı olarak bakı1ırsa; petrol açısından Rusya'nın bugünkü kanıtlanmış petrol rezervlerinin (106,2 milyar varil petrol rezervi (BP, 2018: 12) yaklaşık \%90'ına, Norveç'in sahip olduğu rezervlerin (7,9 milyar varil (BP, 2018: 12) yaklaşık olarak 5 katından fazlasına, Birleşik Arap Emirliklerinin sahip olduğu kanıtlanmış petrol rezervlerinin (97,8 milyar varil BP, 2018: 12) yaklaşık olarak 7 milyar varil eksiği Arktik bölgesinde yer almaktadır.
} 
kullanılabileceği öngörülen "Kuzeydoğu Geçidi (Northwest Passage)" bir başka deniz yolu olarak önem taşımaktadır ${ }^{8}$ (Blunden, 2009: 122).

İklim değişikliğiyle birlikte Arktik Bölgesi’nde açllması beklenen yeni ulaşım yollarıyla birlikte var olan yolların da kullanımın arttırılması mümkün olmaktadır. Bu durum doğrudan enerji taşımacilığını da etkilemesi bakımından Çin ve Rusya Federasyonu için ayrıca bir öneme sahip olmaktadır. Örneğin günümüzde Kuzey Deniz Yolu'nun ${ }^{9}$ taşıma kapasitesi 5-6 milyon ton iken; bu rakamın 2015-2020 döneminde 35-40 milyon tona çıması beklenmektedir (Hasanoğlu, 2015: 179). Dolayısıyla söz konusu taşıma kapasitesi doğrudan petrol taşımacıllğını da etkileyebilmekte ve herhangi bir korsanlık vakası vb. akışı kesen faktörlerin güzergahta var olmaması, yolun var olan önemini daha da arttrrmaktadır (Deniz Haber, 2013).

\section{Harita 6: Arktik Deniz Rotaları (Anonim)}

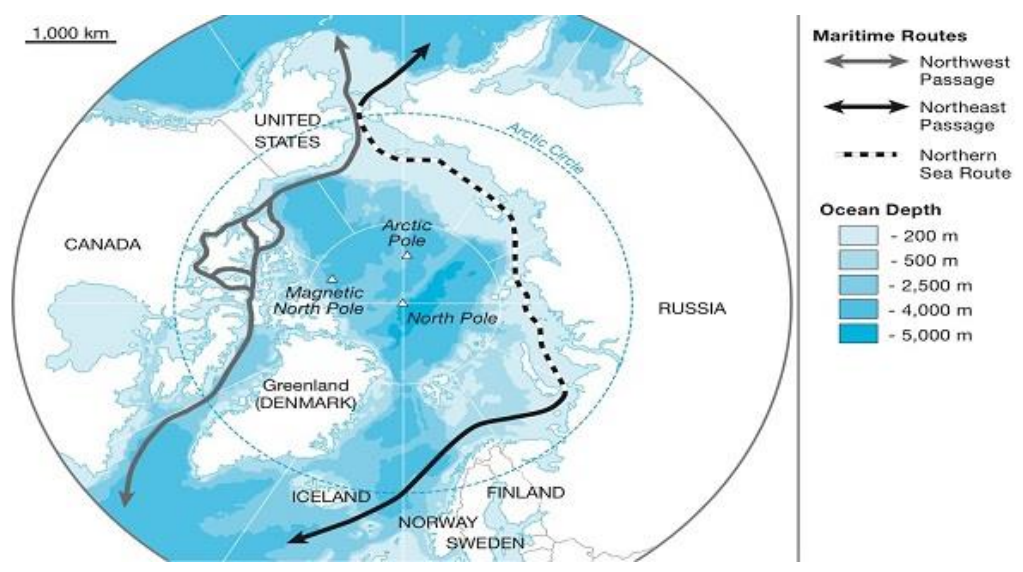

Önemli ölçüde yakın geleceğin jeopolitik mücadele alanı olarak görülen Arktik'te söz konusu mücadelenin sert güç bağlamında çatışmaya neden olabileceği uzmanlarca tartışlmaktadır. Bu olasılık şüphesiz önümüzdeki zaman dilimi için kabul edilebilir olmasına karşın bugün için çeşitli faktörlerin bölgenin fiziki bir çatışmaya konu olmasını engeller nitelikte olduğunu ve dolayısıyla, Arktik'in daha çok işbirliği mekanizmalarının harekete geçirilmesinde etkili olduğunu söylemek mümkündür. Bu noktada

\footnotetext{
${ }^{8}$ Söz konusu geçidin, Yokohama ile Rotterdam arasındaki deniz yolculuğunu, Süveyş Kanalı güzergahına göre $\% 40$ oranında (yaklaşık $5000 \mathrm{~km}$ ) azaltacağı öngörülmektedir (Blunden, 2009: 122).

${ }^{9}$ Kuzey Deniz Yolu'yla ilgili en önemli gelişmelerden birisi Rus gemicilik şirketi Sovkomflot'a ait SFK Baltica adlı yük tankerinin 2010 yllında 113 bin tonluk sıvilaştırılmış doğal gazı Rusya'nın Murmansk kentinden Çin'in Ningbo kentine 22 günde ulaştırmasıdır (Hasanoğlu, 2015: 180). Bu hadisede iki ulaşım noktası arasındaki mesafenin kısalması büyük önem taşımakta ve ileriki zamanlarda taşıma kapasitesinin gelişen teknolojiyle birlikte yeni şartlarla arttırılabileceği beklenmektedir.
} 
en önemli faktörlerin başında şüphesiz coğrafi konum dolayısıyla Arktik ile ilişkisi olan aktörler ve bunların uluslararası sistemdeki konumları gelmektedir. Örneğin, Rusya, ABD, Norveç, Kanada, Danimarka, İsveç, Finlandiya ve İzlanda bölge ile coğrafi konum olarak ilişkili aktörlerden iken, Çin, Japonya, Güney Kore, Hindistan, Singapur ve Türkiye ise coğrafi olarak bölge dişında olmasına karşın, Arktikle ilgilenen uluslararası sistemin diğer büyük ve yükselen güçlerinden bazılarıdır ${ }^{10}$ (Roseth, 2014: 843).

Arktik ile ilgisi olan gerek bölge gerekse bölge dişı ülkelerin uluslararası sistemdeki konumları ve sahip oldukları kapasiteleriyle birlikte, bölgenin daha çok işbirliğine yönelik mekanizmalarının harekete geçirilmesinde etkili olan diğer bir unsur günümüz devletler arası ilişkilerini düzenleyen uluslararası hukuk kurallarının varlığıdır. Aslında bu unsuru genel olarak bölgeyle ilgisi olan ülkelerin uluslararası sistemdeki konumları ve sahip oldukları niteliklerin bir sonucu olarak da değerlendirmek mümkündür. Çünkü fiziki çatışmadan kaçınan ülkelerin, ağırlıklı olarak uluslararası hukuk kurallarına saygılı bir şekilde barışçıl bir çözüme eğilim göstermekte oldukları gözlemlenmektedir. Dolayısıyla, bölge ile ilgili uluslararası hukuk bağlamında çözülmeyi bekleyen sorunlar ${ }^{11}$ genel olarak sistemin önemli aktörlerini işbirliği temelinde bir çözüm arayışına ve bu yönde barışçıl stratejiler belirlemeye yöneltmektedir.

Sonuç olarak, yakın geçmişe kadar tam anlamıyla önem atfedilmeyen Arktik Bölgesi, günümüzde hayati öneme sahip coğrafyalardan birisi olarak görülmekte ve birçok aktör söz konusu coğrafyada etkin olabilmek için çaba göstermektedir. Coğrafyanın önemi şüphesiz sahip olduğu niteliklerden kaynaklanmaktadır. Bölgeyi önemli k1lan nitelikler ise; sahip olduğu enerji kaynakları potansiyeli, yer altı zenginlikleri, yeni ulaşım yollarıdır. Fakat özellikle belirtmek gerekir ki; tüm nitelikler birbiriyle bağlantılı olarak önem kazanmakta, enerji potansiyeli ise bir adım öne çıkmaktadır. Aktörlerin bölgede etkin olabilmek yönündeki çabalarının en önemli göstergesi ise, politik uygulamalarında karşımıza çıkmaktadır. Çin söz konusu aktörlerden birisi olarak ön plana ç1kmaktayken, Pekin'in Arktik bölgesiyle ilgili amaçlarını gerçekleştirmek için yapmış olduğu hamleler, ülkeyi ön plana

\footnotetext{
10 Söz konusu ülkelerden ABD, Kanada, Danimarka (hem NATO hem de Avrupa Birliği üyesi), Norveç, İzlanda'nın NATO üyesi olmasıyla birlikte İsveç ve Finlandiya'nın Avrupa Birliği üyesi olması olduğunu belirtmek gerekmektedir.

11 Arktik'in ülkelere ekonomik olarak sunduğu firsatlar önemli ölçüde uluslararası hukuk çerçevesinde bir çözüme kavuşturulmalıdır. Çünkü bu firsatlardan yararlanabilmek gibi birçok konu genel olarak uluslararası hukuk kapsamında düzenlenmektedir. Ayrıca bölge ile ilgili çözüm bekleyen sorunların ülkeleri fiziki çatışmaya yöneltecek potansiyelde olduğunu da kabul etmek mümkündür. Örneğin, sınır problemleri ile bağlantılı olarak egemenlik alanları gibi Uluslararası Deniz Hukuku'nu ilgilendiren sorunları bu yönde değerlendirmek mümkündür.
} 
çıkaran en önemli etkenlerdendir. Özellikle Çin'in Arktik politikasını grand stratejisiyle ilişkilendirmesi bu aşamada büyük önem taşımaktadır.

\section{Kuşak-Yol Projesi'nde Arktik: Kutup İpek Yolu Vizyonu}

Çin, yakın döneme kadar gündeminde tam olarak yer almamasına rağmen son yıllarda Arktik coğrafyasıyla yakından ilgilenir duruma gelmiştir. Arktik'te ekolojik felaket olarak nitelendirilen küresel iklim değişikliği sonucunda ortaya çıan firsatlar, diğer aktörler gibi Çin'in bölgeye yönelmesinin en önemli nedenleri arasındayken, yeni ticaret güzergahlarının ortaya çıkması ve enerji faktörü, Pekin için daha spesifik olarak ifade edilebilecek fırsatlardır. Ekonomisinin yaklaşık yüzde 60'ından fazlası dış ticarete dayanan Çin'in bu ticaretinin yaklaş1k yüzde 90'ını deniz yoluyla ${ }^{12}$ gerçekleştirmesi (Liang ve Zhang, 2019: 63) ve yeterli miktarda enerji kaynağına sahip olmamasına karşın dünya birincil enerji tüketimindeki yüzde 23,2'lik payıyla (BP, 2018: 8), Arktik'in sunmuş olduğu firsatlar birlikte değerlendirildiğinde Pekin'in bölgeye ilgisi kaçınılmazdır. Ayrıca grand strateji bağlamında değerlendirildiğinde Arktik, Çin için gelecekte Kuşak ve Yolun önemli bir tamamlayıcısı niteliğinde stratejik öneme sahip olacak potansiyeldedir. Pekin yönetimi de şüphesiz söz konusu farkındalık dahilinde siyasi adımlar atmaktadır. Söz konusu adımlardan bir tanesi, 20 Haziran 2017'de Çin Ulusal Kalkınma ve Reform Komisyonu ve Çin Okyanus İdaresi tarafindan yayımlanan "Kuşak ve Yol Girişimi Kapsamında Deniz İşbirliği Vizyonu (Vision for Maritime Cooperation under the Belt and Road Initiative)" belgesiyle Arktik Okyanunusu'nun Kușak-Yol'a dahil edilmesidir. Vizyon belgesiyle "Mavi Ekonomik Geçit (Blue Economic Passage) olarak ifade edilen bu yolla Çin'in ekonomik koridoru genişletilmiş ve Avrupa'ya kuzeyden bağlantı kurulmasının planlandığı resmi olarak dile getirilmiştir (Büyüksağnak, 2017: 1694).

\footnotetext{
12 Dünya ihracatının \%22 si Çin’den deniz yolu ile sağlanırken, Çin’e taşınan kargo ise dünya toplamının \%19'unu oluşturmaktadır (Liang ve Zhang, 2019: 63).
} 


\section{Harita 7: Mavi Ekonomik Geçit (Bennett, 2017)}

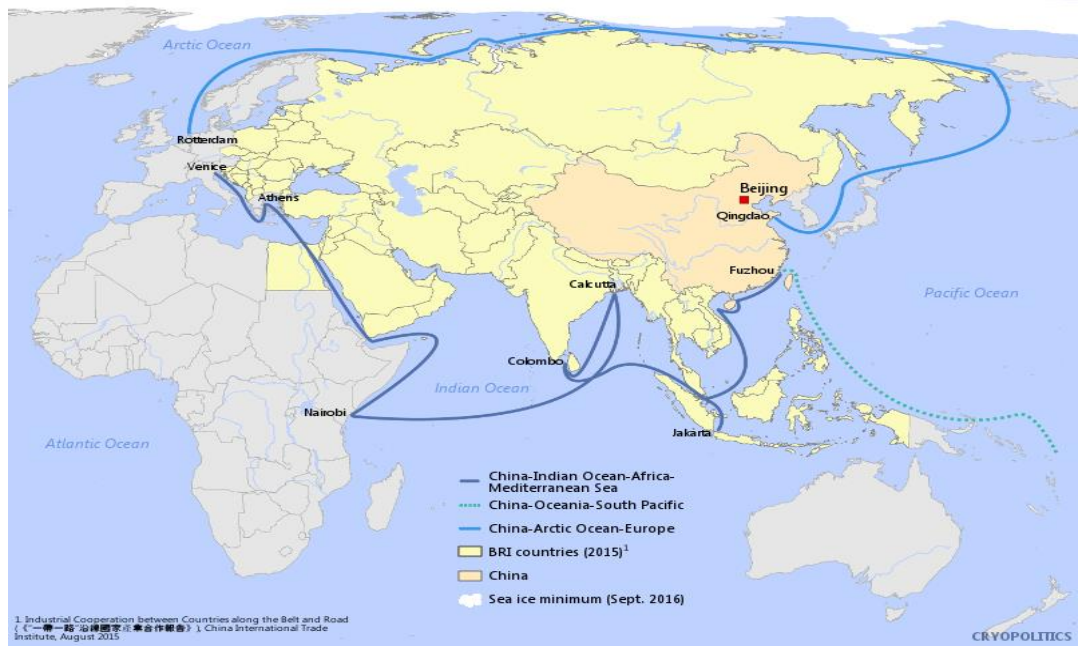

Çin, gerek sunmuş olduğu firsatlar gerek grand stratejinin gelecekte tamamlayıcıs1 olarak nitelendirilen Arktik bölgesiyle ilgili Kuşak ve Yol Girişimi Kapsamında Deniz İşbirliği Vizyonu sonrasında da önemli siyasi adımlar gerçekleștirmeye devam etmektedir. Söz konusu siyasi hamlelerden belki de en önemlisi ve Pekin'in Arktik stratejilerinin dayanağı olarak nitelendirilebilecek, Devlet Konseyi tarafindan 26 Ocak 2018 tarihinde ilan edilen "Çin Arktik Politikası" başılklı "Beyaz Kitap (White Paper)" tır (Çin Halk Cumhuriyeti Devlet Konseyi, 2018). Yakın geçmişte ilan edilen "Beyaz Kitap" ise, Çin'in bölgedeki konumunu ve politikalarını belirlemekle birlikte daha spesifik olarak Arktik boyunca geliştirmeye yönelik Kutup İpek Yolu Vizyonu gibi iddialı bir planın ana hatlarını belirtmektedir (Lim, 2019). Yaklaşık yedi bin kilometre uzakta yer almasına karşın kendisini "Yakem Arktik Ülkesi (Near Arctic State)" olarak nitelendiren Çin tarafindan bölgenin gelişimi ve sunduğu firsatlardan yararlanması bağlamında atmış olduğu somut siyasi hamlelerin başında Kuşak-Yol Projesi ile birlikte ifade edilen "Kutup İpek Yolu Vizyonu" gelmektedir (Axworthy, 2019: 15). Kuşak-Yol Projesi gibi küresel ticaretin arttırlması için ekonomik entegrasyonun sağlam bir şekilde temin edilmesi noktasında küreselleşmenin bir ürünü olarak ortaya çıkan Kutup İpek Yolu Vizyonu, Çin için deniz nakil güzergahlarının çeşitlendirilmesiyle birlikte zaman ${ }^{13}$ ve yakıt tasarrufu noktasında etki yaratabilecek potansiyeldedir. Dolayısıyla, Beyaz Kitapta ilk defa resmi olarak ilan edilen vizyonun temelinde Arktik deniz nakil güzergahlarının geliştirilmesi düşüncesi yatmakta, Kutup İpek Yolu ile ilgili

\footnotetext{
13 Kuzey Rotası Rotterdam'dan Süveyş Kanalı üzerinden Çin'e 48 günde giden bir geminin yolculuk süresini 20 gün kadar kısaltmaktadır (Axworthy, 2019: 15). Şüphesiz yolculuk süresindeki bu azalma doğrudan yakıt tasarrufu anlamına da gelmektedir.
} 
ekonomik açıdan fayda sağlayacak güzergahlara yer verilmektedir. Söz konusu güzergahlar, Rusya kıyısındaki "Kuzeydoğu Geçidi", Kanada kıyısındaki "Kuzeybatı Geçidi” ve Kuzey Kutup güzergahında yer alan “Merkez Geçidi'dir (Axworthy, 2019: 15).

\section{Harita 8: Malakka/Süveyş ve Kutup İpek Yolu Deniz Rotaları (Oxford Analytica, 2018)}



Sonuç olarak Kutup İpek Yolu Vizyonu'nun (The Polar Silk Road Vision), temelde buzulların erimesiyle açı̆̆a çıan Kuzey Hattı'nın Çin tarafindan kendi öncelikleri uyarınca yeninden ele alınmasına dayanmakta olduğunu söylemek mümkündür. Pekin'in bu adımının açık ve en temel nedeni, ihracat devinin şüphesiz kıtalararası özellikle Avrupa'ya mal taşırken sürenin uzunluğu ve maliyetini azaltma çabasıdır (Sağlam, 2018). Birçok uzmanca dile getirilen öngörüler de bu yönde bir amacın varllğını destekler niteliktedir. Örneğin Kuzey Hattı devreye girdiğinde Hamburg ile Şanghay arası Süveyş Kanalı alternatifine göre altı bin dört yüz kilometre, başka bir anlatımla 15 gün kısalacağı öngörülmektedir (Hsiung ve Roseth, 2019: 172).

\section{Arktik'te Enerji ve Rusya - Çin İşbirliği}

Gerek Kuşak-Yol gerekse Kutup İpek Yolu bağlamında olsun Çin'in Arktik'te hedeflediği kazançları elde etmesinin temeli bölgede izleyeceği siyasi anlayışın karakterine dayanmaktadır. Bölge dinamikleri göz önüne alındığında söz konusu siyasi anlayışın karakterinin, barışçıl prensiplere dayalı işbirliği çerçevesinde gelişeceği kuşkusuzdur. İlan edilen Beyaz Kitapla birlikte Kutup İpek Yolu Vizyonu ve öncesindeki açıklamalar söz konusu iddianın en önemli dayanaklarındandır. Örneğin Beyaz Kitap'ın ilan edilmesi öncesinde Pekin, Kutup İpek Yolu Vizyonu'nun Arktik ülkeleri ile çeşitli işbirliği alanlarının kazandırılmasında etkili olacağı yönünde açıklamalarda bulunmuştur (Lim, 2019). Bu bağlamda, Çin de söz konusu resmi beyan ve 
belgeler ışı̆̆ında devletler arası ilişkilerdeki dinamiklerin de farkındalığıyla Kuzey Kutbu'na dönük gelecek vizyonuna kıyıdaşlar ve bölgenin dengelerini gözeterek temkinli yaklaşmaktadır (Sağlam, 2018).

Beyaz Kitap'ta da önceliğinin bölge ülkeleri ile işbirliği vizyonuna dayalı politika anlayışın benimsediğini beyan eden Çin öncelikle Rusya ile ilişkilere biraz daha fazla hassasiyetle yaklaşıldığı gözlemlenmektedir (Lim, 2019). Söz konusu hassasiyette önceki dönemlerde yaşanan gelişmeler, dönemin şartları ve devletlerin tavırlarındaki değissimler, Rusya'nın bölge dengelerindeki konumu ve sahip olduğu nitelikler şüphesiz etkili olmaktadır. Örneğin değişen dinamikler ve tavırlardaki değişim bağlamında incelendiğinde, önceki dönemlerde genel olarak bilindiği üzere Rusya, özellikle üretim alanında Çin menşeili yatırımcıları Arktik enerji projelerine dahil etme yanlısı değilken (Hsiung ve Roseth, 2019:175) son zamanlarda çeşitli çeşitli nedenlerle bu tavrında değişim yaşandığı ve bu doğrultuda tarafların işbirliğine yöneldiği gözlemlenmektedir. Söz konusu tavır değişikliği ve işbirliğine yönelimin temelinde şüphesiz, Çin'in finansal gücü14, Arktik'teki enerji kaynaklarının yaklaşı1k yüzde $80^{\prime}$ inin $^{15}$ Rusya egemenlik sahası içerisinde olmasıyla birlikte ülkenin Kutup İpek Yolu güzergahına konumu (Alexeeva ve Lasserre, 2018: 280) ve Ukrayna Krizi sonrası uygulamaya konulan Batı menşeili yaptırımlar bulunmaktadir.

Arktik bölgesi özelinde Rus-Çin enerji ilişkilerindeki işbirliği için 2013 ylında varılan anlaşma, önemli bir dönüm noktasıdır. 270 milyar dolar hacmindeki söz konusu anlaşma öncelikle iki taraf arasındaki işbirliğine olumlu yöndeki katk1 sağlarken, daha önemlisi bölgede enerji alanında gerçekleştirilen aktivitelere Çin tarafinın ortak olarak davet edilmesine, kısacası ilişkilerde daha ileri bir aşamaya geçmesine ortam hazırlamışır (Pinchuk, 2013). Bu bağlamda, taraflar arasında akdedilen anlaşmayla birlikte Rosneft, Çin Ulusal Petrol Şirketi'ni (CNPC) Barents ve Pechora denizlerindeki üç offshore alan ve Nenetsk bölgesindeki onshore alanlarda keşif çalışmaları yapmaya davet etmiştir. Ancak daha somut nitelikli adımlar Eylül 2016 yllında atılmış ve Çin'e Arktik sahanlığında yer alan Barents ve Chukchi denizlerinde iki blok için lisans verilmiştir (Hsiung ve Roseth, 2019: 175).

Kuzeybat1 Sibirya'da Yamal yarımadasındaki LNG $^{16}$ terminali konusundaki çalışmalar, Arktik bölgesinde Rusya ile Çin arasındaki enerji

14 Rusya Arktik offshore projelerinde uzun süreden beridir Batı menşeili şirketlerle çalışmaktaydı ve bu projeler ciddi teknolojik altyapıyı ve finansal yatırımları gerekli kılmaktadır. Bu nedenle Çin'in finansal gücü Rusya için hayati önem taşımaktadır.

15 Haziran 2017'de yayımlanan "Emerging Chinese-Russian Cooperation in the Arctic" başlıklı SIPRI Policy Paper 46'ya göre offshore olarak kutup dairesinde var olduğu tahmin edilen doğal gazın yaklaşık yüzde 90'1, petrolün ise yaklaşık yüzde 45'inin Rusya'nın Arktik sahanlı̆gında bulunduğu belirtilmektedir (Sorensen ve Klimenko, 2017: 14).

16 "Liquefied Natural Gas" (Sıvılaştırılmış Doğal Gaz). 
alanındaki işbirliği kapsamında somut sonuçların elde edildiğini gösteren ve başarllı sayılabilecek projelerin başında yer almaktadır. ${ }^{17} 2013$ yllı sonlarında başlatılmakla birlikte dünyanın en büyük ve karmaşı LNG projelerinden biri olan Yamal LNG projesinin katılimciları, yüzde 50,1 ile Rus Novatek Şirketi, yüzde 20 ile Fransız TOTAL şirketi, yüzde 20 ile CNPC ve yüzde 9,9 ile Kuşak-Yol kapsamında oluşturulan Çin İpek Yolu Fonu'dur (TOTAL, 2019). 1,3 trilyon metre küp rezerv olduğu ifade edilen ve 27 milyar metre küp ylllık üretim potansiyeli bulunan Yuzhno-Tambeyskoe doğal gaz sahasından sağlanan tedarikle devreye sokulan tesis günümüzde üç sıvılaştırma ünitesiyle faaliyet göstermektedir (Neftegas, 2010). Söz konusu üniteler dahilinde tesis yllda 16,5 milyon ton LNG üretme kapasitesine sahip konumda olmakla birlikte ilk LNG sevkiyatını Aralı 2017'de gerçekleştirmiştir (Sputniknews, 2018). Gerekli olan ekipmanların yaklaşık yüzde 80'ni Çin tersanelerinde üretilen Yamal LNG'nin finansmanı konusunda, Nisan 2016'da Çin Exim Bank ve Çin Kalkınma Bankası projeye 19,1 milyar Avro civarında bir kredi sağlarken, Çin genel olarak projenin yaklaşık yüzde 60'nı finanse etmiş durumdadır. Öyle ki projenin toplam maliyeti 2016 yllı için yaklaşık 27 milyar dolar olarak ifade edilmektedir (Yulong, Linghao ve Jia, 2016: 13-14).

Yamal LNG, Çin grand stratejisi ve Kuşak-Yol projesi bağlamında değerlendirildiğinde Rusya ile yürütülen projelerden bir adım daha öneme sahip konumda yer aldığ gözlemlenmektedir. İpek Yolu Fonu'nun Novatek'in hisselerini satın olarak ortak olmasıyla birlikte önemli ölçüde Kuşak-Yol Projesinin finans kaynaklarından projeye kaynak aktarıyor olması bir nevi Yamal LNG'nin ${ }^{18}$ grand stratejiyle birleştirildiğinin göstergelerindendir. Çin medyasının "Yamal LNG'yi Kuşak-Yol Girişiminin ilk enerji projesi" olarak kutlaması da söz konusu birleşimi doğrular niteliktedir (Filimonova ve Krivokhizh, 2018).

\section{Kutup İpek Yolu Vizyonunda Enerji Nakil Güzergahı Olarak Kuzey Deniz Rotası: Rusya-Çin İşbirliği}

Kutup İpek Yolu çerçevesinde Rusya ve Çin arasında yürütülen işbirliği alanlarından bir diğeri enerjiyle bağlantılı olarak da değerlendirebileceğimiz Kuzey Deniz Rotası'dır. Kuşkusuz söz konusu rota ülkenin dış ticaretine büyük katkı yapacak nitelikteyken aynı zamanda enerji bağlamında değerlendirildiğinde ihtiyacının büyük bir kısmını dışarıdan temin eden Pekin

\footnotetext{
${ }^{17}$ Novatek Yönetim Kurulu Başkanı Leonid Michelson’un Aralık 2017 tarihinde ifade ettiğine göre; "Yamal LNG, küresel LNG pazarndaki yaklaşı yüzde 5'lik payzyla șu anda Rusya'nm en büyük LNG Projesi durumundadr" (LNG World News, 2018).

18 Yamal yarımadasının coğrafi konumu göz önüne alındığında söz konusu birleşimin nedeni doğrudan anlaşılabilmektedir. Projenin başlangıcında sahaya karadan ve denizden hiçbir şekilde ulaşım imkânı bulunmamaktaydı. Ekipmanların ve personelin transferini kolaylaştırmak için 2011 ylında Sabetta limanı ve uluslararası havaalanı niteliğindeki bir bölgesel ulaşım merkezi inşaatına başlanmıştır (TOTAL, 2019).
} 
için Kuzey Deniz Yolu'nu daha da önemli kilmaktadır. Petrol ithalatının yaklaşık yüzde 80'nin Malakka Boğazı'ndan geçmesi, 2040'lı yıllarda enerji ithalatı bağımlılık oranının ciddi oranda artacağı ve bunun için yaklaşık olarak yılda yarım trilyon dolar harcama yapacağı öngörülmesi, Kuzey Deniz Rotası'nın Çin için taşıdığı önemin anlaşılması noktasında örnek olarak verilebilir (International Energy Agency, 2017). Kısacası, enerji bağlamında incelendiğinde Kuzey Deniz Rotası gerek enerji ithalatında tedarikçilerin çeşitlendirilmesi gerekse de nakil güzergahlarının çeşitlendirilmesi bakımından Çin'in enerji güvenliğine katkı yapması bağlaminda önem taşımaktadır. Söz konusu katkı kuşkusuz Çin’in bölge ülkeleri ilişkileri bağlamında da geçerliliğini korumaktadır.

Kuzey Deniz Rotası ile ilgili Rusya-Çin arasındaki enerji alanındaki işbirliğine katkı sağlaması açısından bakıldığında, LNG konusu ön plana ç1kmaktadır. Taraflar arasında tam anlamıla aktif olarak faaliyet gösteren doğal gaz nakil hattı(ları) olmaması, LNG'nin enerji alanındaki işbirliği konusunda ön plana çıkmasında etkiliyken, şüphesiz maliyetlerin de bu konuyu desteklediği gerçektir. Örneğin Çin tarafinca Orta Asya'dan doğal gazın boru hatlarıyla temin edilmesiyle LNG olarak temin kiyaslandığında ekonomik olarak maliyetlerin arttığ1 ve LNG'nin daha ucuza temin edildiği bilinmektedir (Research and Markets, 2019). Bu bağlamda Kuzey Deniz Rotası ile ilgili elde edilen sonuçların önemlilerinden ilkinin LNG taşımacılığında meydana gelmesi Rusya-Çin enerji ilişkilerinde LNG'nin pozisyonunu destekler niteliktedir.

Kuzey Deniz Rotası yoluyla ilk LNG transit denemesi Ağustos 2010 tarihinde Rusya'nın Murmansk limanından Çin'in Ningbo limanına gerçekleştirilmiştir (Hsiung ve Roseth, 2019: 173). Söz konusu başarılı deneme ilk olmasıyla birlikte taraflar arasındaki ilişkilerdeki birçok gelişmeyi tetiklemesi açısından öneme sahipken, Rusya ve Çin arasında yapılan anlaşmalar bu durumun en önemli göstergelerindendir. Denemeden kısa bir süre sonra ticari alanda yapılan anlaşma, bu noktada örnek olarak gösterilebilir. Öyle ki Rusya'nın en büyük denizcilik şirketi Sovcomflot Group ve CNPC Kuzey Deniz Rotası boyunca petrol taşımacılığının da dahil edildiği Arktik deniz seferi için personel yetiştirilmesine yönelik uzun dönemli çerçeve anlaşmasına varmışlardır (Hsiung ve Roseth, 2019: 173).

Kuşak-Yol'un önemli bir tamamlayıcısı olarak ifade edilen Kutup İpek Yolu Vizyonu bağlamında incelendiğinde taraflar arasında Kuzey Deniz Rotası temelinde yürütülen enerji işbirliği için 2017 y1lı önemli bir milattır. Mayıs 2017 tarihinde Putin, Pekin'de düzenlenen Kuşak ve Yol Forumu'nda Arktik gemi rotaları ile ilgili çalışmaların Kuşak ve Yol ile entegre edileceğini açıklanması bu noktada büyük önem taşımaktadır. Söz konusu açıklamanın yaklaşık olarak iki ay sonrasında gerçekleşmiş ve dönemin Rusya Başbakanı Medvedev ile Xi Jinping, Arktik ile ilgili çalışmaların Kutup İpek Yolu 
vizyonu kapsamında yapılacağını açıklamış ve Kasım 2017'de Pekin ziyareti sırasında bu ifadesini tekrar etmesiyle daha somut adımlar atılmıştır. Ayrıca Medvedev'in ziyareti sonrasında Kutup İpek Yolu terminolojik olarak iki tarafça da kullanılmaya başlanmıştır (Sun, 2018: 3).

Kuşak-Yol'un önemli bir tamamlayıcısı olarak nitelendirilen Kutup İpek Yolu Vizyonu kapsamında ele alabileceğimiz ve Rusya-Çin arasındaki enerji işbirliği ile ilişkili olan Kuzey Deniz Rotası ile ilgili tarafların atmış olduğu adımlar sınırlı olarak kalmıştır. Güzergâh ile ilgili yatırımlara konu ile ilgili kaynaklarda rastlanabilmekteyken, spesifik olarak Kutup İpek Yolu bağlamında enerji ilişkili yapılan yatırımlara ve yürütülen projelere tam olarak rastlanamamaktadır. Resmi beyanlar da bu yöndedir. Öyle ki Pekin'in resmi açıklamalarında enerji, nükleer, havacılık, sınır, alt yapı gibi projeler ortaklık yürütülen kilit stratejik projeler olarak ifade edilirken bu alanların hiçbirinde doğrudan Kuzey Deniz Rotasına salt olarak yer verilmemektedir (Sun, 2018: 9). Ancak bu ifade çalışmaların da olmadığı anlamına gelmemektedir. Kuzey Deniz Rotası birçok alanda geliştirilen ve stratejik olarak nitelendirilen projelerin bir parçası ya da tamamlayıcısı olarak güzergah ile ilgili çalışmaların yürütüldüğü bilinmektedir. Arktik LNG 2 projesi, söz konusu çalışmalardan olup, gelecek dönemlerde de bunların devam edeceğinin göstergelerindendir.

\section{Sonuç}

Günümüz uluslararası sisteminin başat aktörlerinin gerek temel çıkarları gerekse devletlerarası ilişkilerdeki pozisyonları nedeniyle özü ile doğru orantılı olacak şekilde zorunlu olarak stratejiler belirlemekte ve bu yönde siyasi hamleler gerçekleştirmelidirler. Söz konusu stratejiler, spesifik alanlarda olabileceği gibi belirli kriterler çerçevesinde grand strateji olarak da karşımıza çıkabilmektedir. Ancak grand stratejinin herhangi bir devletin çıkar hedefleri doğrultusunda ifade edilen stratejilerle karıştırılmaması gerektiğini tekrardan belirtmek gerekmektedir. Dolayısıyla grand strateji konsepti, tamamen belirli kriterler çerçevesinde devletin ulusal güvenlik hedefleri bağlamında ve bu hedeflere ulaşmada kullanacağı en uygun araçların seçilmesi bağlamında sahip olduğu genel vizyon olarak tanımlanmaktadır.

Bir devletin dış politikasının hayati unsuru olarak ifade edilen grand strateji bağlamında siyasi hamleler gerçekleştiren uluslararası sistemin önemli aktörlerinden birisi Çin'dir. Devletin hayati çıkarlarını ve nihai hedeflerine ulaşabilmesinin temeline ekonomik unsurları yerleştiren Çin için Kuşak-Yol Girişimi bu doğrultuda grand strateji niteliğindedir. Girişimin ayrıntıları ve atılan adımlar göz önüne alındığında, stratejinin niteliği kolayca anlaşılmaktadır. Eski İpek Yolu'nun canlandırılması temelinde gelişen Çin'in grand stratejisi, Kuşak ve Yol olarak birbirini bütünleyen iki parça şeklinde ifade edilirken, planın temelindeki anlayışın tetiklediği unsurlar küresel çaptaki etki bağlamında büyük öneme sahiptir. Kazan-kazan prensibiyle 
birlikte barışçıl bir etkileşim çerçevesinde şekillenen söz konusu anlayış ve küresel etkileri bu noktada ön plana çıkmakta, dolayısıyla devletlerarası etkileşimlere önemli ölçüde işbirliği zemini, Kuşak-Yol Girişimi çerçevesinde kazandırılması hedeflenmektedir. Söz konusu işbirliği zemini ise yeryüzünü oluşturan kara parçalarının yaklaşık yüzde 40’ını, dünya nüfusunun yaklaşık yüzde 65’i ve küresel ekonominin ise yüzde 30'undan fazlasinı bir araya getiren yetmişe yakın devlet arasındaki etkileşimle ifade edilmektedir. Grand stratejisinin temeline ekonomik unsurları konumlandıran Çin için bu işbirliği, yaklaşık olarak 21 trilyon dolar hacminde devletler topluluğu ile etkileşim ve ayrıca spesifik olarak söz konusu devletlerin nitelikleri göz önüne alındığında, birçok alanda güvenlik tehditlerinin önüne geçilmesi anlamına gelmektedir. Hem ekonominin ana lokomotifi hem de devletlerin varlıklarını sürdürebilmelerinin temelinde yer alan enerji konusu ve dolayısıyla enerji güvenliği bağlamındaki firsatlar bu noktada büyük önem taşımaktadır.

Grand strateji çerçevesinde değerlendirilmesi gereken Kuşak-Yol Girişimi 1şı̆̆ı̆nda etkileşim içerisinde olunan devletlerin nitelikleri doğrudan proje bağlamında atılacak adımları ve Çin’in işbirliği ortakları arasındaki konumlarını tetiklemektedir. Günümüz uluslararası sistemindeki meydana gelen gelişmelerle birlikte Çin için ekonomi, enerji ve güvenlik gibi önemli unsurlar göz önüne alındığında ilk aşamada devletlerarası etkileşimde öncelik verilmesi gereken aktör şüphesiz Rusya'dır. Dolayısıyla Pekin bunun bilincinde hareket etmekte ve Moskova ile ilişkilerini sağlamlaştırmaktadır.

Rusya açısından bakıldığında ise, Çin'in grand stratejisi temelindeki kazan-kazan anlayışı ve Moskova'nın içinde bulunduğu şartlar da devleti Çin'e yakınlaştırır niteliktedir. Bununla birlikte günümüz şartları şemsiyesi altında ifade edilebilecek dinamikler taraflar arasındaki işbirliği alanını da ortaya koymaktadır. Söz konusu işbirliği açıkça görüldüğü üzere öncelikle enerji alanında yürütülmektedir. Fakat bu noktada özellikle belirtmek gerekir ki Kuşak-Yol Girişimi Rusya-Çin enerji alanındaki genel olarak yürütülen işbirliğinden daha spesifik, yeni ve plan kapsamında değerlendirilebilecek bir ortaklığa ivme kazandırmaktadır. Spesifik ortaklık ise, önemli ölçüde yakın geleceğin jeopolitik mücadele alanı olarak görülen Arktik coğrafyasılla ilişkili olarak enerji alanında gün yüzüne çıkmaktadır.

Taraflar arasındaki spesifik olarak ifade edilen işbirliğinin temel dayanaklarından birisi Çin tarafından yayımlanan "Beyaz Kitap" ile birlikte Kuşak-Yol Girişimine entegre olarak ilan edilen küresel ölçekte etki yaratabilecek potansiyele sahip "Kutup İpek Yolu” projesidir. Sonuç olarak son dönemdeki gelişmeler 1şı̆̆ında "Beyaz Kitap" öncelikle Kuşak-Yol Girişimine güncellik kazandırmakla birlikte, Çin grand stratejisi çerçevesinde gerekli görülen nitelikleri güçlendirmek, kazan-kazan prensibi temelinde barışçıl bir anlayışla Rusya ve Çin gibi iki küresel sistemin yakın geleceğin 
jeopolitik mücadele sahasında, hayati önemdeki bir alanda işbirliği zemini oluşturması bakımından büyük önem taşımaktadır. 


\section{Kaynakça}

Akın, G. (2013) "Yüzyılımızın Temel Sorunlarından Biri; Buzulların Erimesi", Ankara Üniversitesi Dil ve Tarih-Coğrafya Fakültesi Antropoloji Dergisi, (25): 9-27.

Alexeeva, O. ve Lasserre, F. (2018) "An Analysis on Sino-Russian Cooperation in the Arctic in the BRI Era", Advances in Polar Sciences, 29(4): 269-282. DOI: 10.13679/j.advps.2018.4.000xx.

Axworthy, T. S. (2019) "The Polar Silk Road", China Today, https://www.interactioncouncil.org/media-centre/polar-silk-road, : 14-16, (erişim tarihi: 02.06.2019).

Bennett, M. (2017) "China Plans Arctic Belt and Road Initiaves", The Maritime Executives, https://www.maritimeexecutive.com/editorials/china-plans-arctic-belt-and-roadinitiatives, (erişim tarihi: 10.07.2019).

Blunden, M. (2009) "The New Problem Of Arctic Stability”, Survival, 51(55): 121-142. DOI: https://doi.org/10.1080/00396330903309899.

British Petroleum. (2018) BP Statistical Review of World Energy Report, British Petroleum.

Büyüksağnak, Y. B. (2017) “Kuzey Buz Denizi’ndeki Gelişmelerin Çin Deniz Taşımacılığına Etkisi”, II. International Academic Research Congress (INES) Tam Metin Kitab1, 18-21 Ekim 2017 AlanyaAntalya, 1690-1697.

Çin Halk Cumhuriyeti Devlet Konseyi, (2015) "Full Text: Action Plan on the Belt and Road Initiative", http:/ / english.gov.cn/archive/publications/2015/03/30/content_ 281475080249035.htm (erişim tarihi: 30.05.2019).

Çin Halk Cumhuriyeti Devlet Konseyi, (2018) "White Paper: Full Text China's Artic Policy", http://english.gov.cn/archive/white_paper/2018/01/26/content _281476026660336.htm (erişim tarihi: 31.05.2019).

Danner, L. K. (2018) China's Grand Strategy: Condictory Foreign Policy?, Pelgrave Macmillan: Cham.

Deniz Haber. (2013) "Kuzey Deniz Yolu: Buzsuz ve Korsans1z", https:/ /www.denizhaber.net/kuzey-deniz-yolu-buzsuz-vekorsansiz-haber-50662.htm (erişim tarihi: 31.05.2019.

Desjardins, J. (2016) "Four Maps Showing China's Rising Dominance in Trade", Visual Capitalist, https://www.visualcapitalist.com/four-maps- 
showing-chinas-rising-dominance-trade/ (erişim tarihi: 10.07.2019).

Durdular, A. (2016) “Çin'in Kuşak-Yol Projesi ve Türkiye-Çin İlişkilerine Etkisi”, Avrasya Etüdleri, (49/2016-1): 77-97.

Filimonova, N. ve Krivokhizh, S. (2018) "China's Stakes in the Russian Arctic", https://thediplomat.com/2018/01/chinas-stakes-in-therussian-arctic/ (erişim tarihi: 09.06.2019).

Gümrükçü, H. (2015) "Kutup Çağının Genel Hatları”, H. Gümrükçü, N. Shulgina Şanll, S. Demirkılınç, A. İnan, T. İlbuğa (Ed), Küresel Bakışla Kutup Cağg: Catısmalar, İsbirlikleri ve Ulusal Çıkarlar, Siyasal Kitapevi, Ankara, 4-26.

Güner, B. (2018) “OBOR Girişimi’nin Coğrafyası”, Marmara Coğrafya Dergisi, (37): 112-123. DOI: $10.14781 / \mathrm{mcd} .386165$.

Güneş, (2018) “Tonga da Çin'in Kuşak-Yol Projesine Katıldı”, https:/ /www.gunes.com/dunya/tonga-da-cinin-kusak-yolprojesine-katildi-929644 (erişim tarihi: 10.07.2019).

Kohli, H. (2017) "Looking at China's Belt and Road Initiative From The Central Asian Perspective", Global Journal of Emerging Market Economies, 9(1-3): 3-11.

DOI: https://doi.org/10.1177/0974910117747760.

Hasanoğlu, İ. (2015) "Kutup Çağının Genel Hatları”, H. Gümrükçü, N. Shulgina Şanlı, S. Demirkılınç, A. İnan, T. İlbuğa (Ed), Küresel Bakışla Kutup Căğ: Catısmalar, Isşbirlikleri ve Ulusal Çıkarlar, Siyasal Kitapevi, Ankara, 165-186

Heininen, L., Alexander, S. ve Yarovoy, G. (2014) Russian Strategies In The Arctic: Avoiding A New Cold War, (Valdai Discussion Club Report).

Hsiung, C. W. ve Roseth, T. (2019) "The Arctic Dimension in Sino-Russian Relations", J. I. Bakkevold ve B. Lo (Ed.), Sino-Russian Relations in the 21st Centruy, Palgrave Macmillian, Cham, 167-187.

Hu, W. R. (2017) “China's One Belt One Road Strategy: Opportunity or Challange for India", China Report, 53(2): 107-124. DOI: https://doi.org/10.1177/00094455517696619.

Ingenfald, E. (2010) "Just in Case Policy in the Arctic", Arctic, 63, (2): 257259. DOI: $10.14430 / \operatorname{arctic} 989$.

International Energy Agency. (2017) "World Energy Outlook 2017: China", https://www.iea.org/weo/china/i (erişim tarihi: 15.06.2019). 
International Sustainable Resilience Center (ISRC), (2018) "Public Pivate Partnership and The Belt and Road Initiative", https://ippprc.org/beltand-road-initiative (erişim tarihi: 10.07.2019).

Kardaş, T. (2014) "Güvenlik”, Ş. Kardaş ve A. Balcı (Ed.), Uluslararası İliskilere Giriş, Küre Yayınları, İstanbul, 325-337.

Kassab, H. S. (2018), Grand Strategies of Weak States and Great Powers, Palgrave Macmillian, Cham.

Kohil, H. (2018) "Looking at China's Belt and Road Initiative From the Central Asian Perspective", Global Journal of Emerging Market Economies, 9(1-3): 3-11. DOI: https://doi.org/10.1177/0974910117747760.

Liang, H. ve Zhang, Y. (2019) The Theoretical System of Belt and Road Initiative, People's Publishing House ve Springer Nature Singapore, Pekin.

Lim, K. S. (2019) China's Arctic Policy and the Polar Silk Road Vision, (Arctic Yearbook 2018), https://arcticyearbook.com/images/yearbook/2018/Scholarly_Pa pers/24_AY2018_Kong.pdf_(erişim tarihi: 31.05.2019).

LNG World News, (2018) "Yamal LNG Ramps Up to Full Capacity", https:/ / www.lngworldnews.com/yamal-lng-ramps-up-to-fullcapacity/(erişim tarihi: 09.06.2019).

Dunford, M. ve Liu, W. (2019) "Chinese Perspectives on the Belt and Road Initiative", Cambridge Journal of Regions, Economy and Society, 12(1): 145-167. DOI: https://doi.org/10.1093/cjres/rsy032.

Murray, W. (2011) “Thoughts on Grand Strategy", W. Murray, R. H. Simmreich ve J. Lacey (Ed.), The Shaping of Grand Strategy: Policy, Diplomacy and War, Cambridge University Press: New York, 1-34.

Neftegas. (2010) "Russian Novatek Will Finish the Construction of Its Yamal LNG Plant by 2018”, https://neftegaz.ru/en/news/oil/413871-russian-novatek-willfinish-the-construction-of-its-yamal-lng-plant-by-2018/ (erişim tarihi: 14.06.2019).

Oxford Analytica. (2018) "Polar Silk Road Map", https:/ /dailybrief.oxan.com/g/oxweb/GI238580/2018-09-18polar-silk-road-map_1000.png (erişim tarihi: 10.07.2019)

Özdaşl1, E. (2015) “Çin’in Yeni İpek Yolu Projesi ve Küresel Etkileri”, Turkish Studies, 10/14: 579-596.

DOI: $10.7827 /$ TurkishStudies.8879. 
Pinchuk, D. (2013) "Rosneft to Double Oil Flows to China in $\$ 270$ Billion Deal", https://www.reuters.com/article/us-rosneft-china/rosneftto-double-oil-flows-to-china-in-270-billion-dealidUSBRE95K08820130621(erişim tarihi: 09.06 2019).

Ploberger, C. (2017) “One Belt, One Road: China’s New Grand Strategy”, Journal of Chinese Economic and Business Study, 15(3): 289-305. DOI: https://doi.org/10.1080/14765284.2017.1346922.

Research and Markets. (2019) "Research Reports on Natural Gas Import in China 2019-2023", https://www.researchandmarkets.com/reports/4769665/research -report-on-natural-gas-import-in-

china?utm_source=GNDIY\&utm_medium $=$ PressRelease\&utm_c ode $=3$ txkt9\&utm_campaign $=1243136+$ -

+The+Natural+Gas+Import+Market+in+China+to+2023\%3a+ Demand + is + Expected + to + Keep + Rising\&utm_exec $=$ joca220prd (erişim tarihi: 15.06.2019).

Roseth, T. (2014) “Russia’s China's Policy in the Arctic", Strategic Analysis, 38(6): 841-859.

DOI: https://doi.org/10.1080/09700161.2014.952942.

Sağlam, M. (2018) "Çin Kutup İpek Yolu'nu Mu Bekliyor?", https:/ /www.gazeteduvar.com.tr/yazarlar/2018/01/31/cin-kutupipek-yolunu-mu-bekliyor/ (erişim tarihi: 03.06.2019).

Sancak, K. (2019) "Deniz Hukukuna İlişkin Temel Egemenlik Alanları Bağlamında Arktik'teki İhtilaflı Alanlar ve Hukuki Durum", Uluslararasi İktisadi ve İdari Incelemeler Dergisi, 23(17): 17-34. DOI: https://doi.org/10.18092/ulikidince.455557.

Schmidt, B. C. (2016) “Ulusal Güvenliğin Önceliği”, S. Smith, A. Hadfield ve T. Dunne (Ed.), (Çev. N. Uslu), Dıs Politika Teoriler, Aktörler, Örnek Olaylar, Röle Akademik Yayıncılık, İstanbul, 188-203.

Scrafton, M. (2018) "Grand Strategy: All Along the Polar Silk Road", https:/ / www.aspistrategist.org.au/grand-strategy-along-polar-silk$\mathrm{road} /$ (erişim tarihi: 20.05.2019).

Sergunin, A. ve Konyshev, V. (2014) "Russia in Search of Its Arctic Strategy: Between Hard and Soft Power", The Polar Journal, 4, (1): 69-87. DOI: https://doi.org/10.1080/2154896X.2014.913930.

Sevilla, H. A. J. (2017) “China's New Silk Route Strategy and Association of the Southeast Asian Nations", Indian Journal of Assian Affairs, 30(12): 85-91. 
Sheng, A. (2017) “OBOR and EuroAsia's New Great Game”, China Report, 53(2): 232-252. DOI: https://doi.org/10.1177/0009445517696642.

Sorensen, C. T. N., ve Klimenko, E. (2017) "Emerging Chinese-Russian Cooperation in the Arctic", SIPRI Policy Paper 46.

Sputniknews. (2018) “Novatek: Arktik'teki Yamal LNG Projesindeki Üçüncü Ünite Devreye Girdi”, https://tr.sputniknews.com/rusya/201812121036598367-novatekarktik-yamal-lng-projesi-uc-unite-hizmete-girdi/ (erişim tarihi: 09.06.2019).

Sun, Y. (2018) "The Nothern Sea Route: The Myth of Sino-Russian Coorperation", https://www.stimson.org/sites/default/files/fileattachments/Stimson $\% 20$

$\% 20$ The $\% 20$ Northern $\% 20$ Sea $\% 20$ Route $\% 20$ -

$\% 20$ The $\% 20$ Myth $\% 20$ of $\% 20$ Sino-Russian $\% 20$ Cooperation.pdf (erişim tarihi: 15.06.2019).

Şöhret, M. (2011) "Çin'in Ulusal Güvenlik Stratejisi", http://www.bilgesam.org/incele/848/-cin'in-ulusal-guvenlikstratejisi/\#.XPwtDC3BKF0 (erişim tarihi: 09.06.2019).

Tekir, O. ve Demir, N. (2019) "Çin'in Yeni İpek Yolu Girişimi ve Küresel Ekonomik ve Siyasal Sistemi Dengeleyebilme Olasillŭgı", Yönetim ve Ekonomi, 26(1): 263-276.

TOTAL. (2019) "Yamal LNG: The Gas That Came in From The Cold", https://www.total.com/en/energy-expertise/projects/oilgas/lng/yamal-lng-cold-environment-gas (erişim tarihi: 09.06.2019).

Uluslararası Politika Akademisi. (2017) "Yeni İpek Yolu Projesi Nedir?", http://politikaakademisi.org/2017/12/23/yeni-ipek-yolu-projesinedir/ (erişim tarihi: 30.05.2019).

Westly, E. (2007) "Arctic Land Grabs Could Cause Eco-Disaster", http://discovermagazine.com/2007/aug/arctic-land-grabs-couldcause-eco-disaster (erişim tarihi: 31.05.2019).

Yiğenoğlu, K. (2018) “Çin'in Tek Kuşak Tek Yol Projesi ve Asya Altyap1 Yatırım Bankası”, Yönetim, Ekonomi, Edebiyat, İslami ve Politik Bilimler Dergisi, 3(1): 10-28. DOI: https://doi.org/10.24013/jomelips.387168.

Young, O. (2012) "Arctic Politics in an Era of Global Change", The Brown Journal of World Affairs, 9(1): 165-178. 
Yulong, L., Linghao, K. ve Jia, L. (2016) "Yamal LNG Project and Made in China Equipment Going Globally", China Oil and Gas, (3): 13-17. 